Article

\title{
Intermediates Transformation of Bornite Bioleaching by Leptospirillum ferriphilum and Acidithiobacillus caldus
}

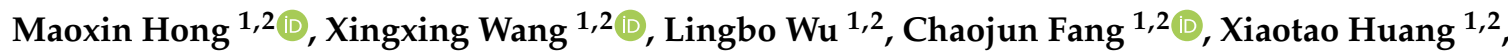 \\ Rui Liao ${ }^{1,2}$, Hongbo Zhao ${ }^{1,2}$, Guanzhou Qiu ${ }^{1,2}$ and Jun Wang 1,2,* \\ 1 School of Minerals Processing \& Bioengineering, Central South University, Changsha 410083, China; \\ maoxinhong@csu.edu.cn (M.H.); wangxingxing@csu.edu.cn (X.W.); wulingbo@csu.edu.cn (L.W.); \\ fangchaojun1009@126.com (C.F.); huangxiaotao810@163.com (X.H.); csuliaorui@163.com (R.L.); \\ zhbalexander@csu.edu.cn (H.Z.); qgz@csu.edu.cn (G.Q.) \\ 2 Key Laboratory of Biohydrometallurgy of Ministry of Education, Changsha 410083, China \\ * Correspondence: wjwq2000@126.com; Tel.: +86-0731-8887-6557
}

Received: 25 January 2019; Accepted: 1 March 2019; Published: 7 March 2019

\begin{abstract}
Bioleaching experiments, electrochemical tests, X-ray diffraction (XRD), and X-ray photoelectron spectroscopy (XPS) were conducted to investigate the intermediates transformation of bornite by Leptospirillum ferriphilum and Acidithiobacillus caldus. The bioleaching experimental results showed that the presence of $L$. ferriphilum and A. caldus significantly accelerated the bornite bioleaching. In addition, the intermediate species of bornite bioleaching with these two kinds of bacteria were similar. Electrochemical analysis indicated that the dissolution of bornite was an acid-consuming process. The results of XRD showed that intermediate species, namely covellite (CuS), mooihoekit $\left(\mathrm{Cu}_{9} \mathrm{Fe}_{9} \mathrm{~S}_{16}\right)$ and isocubanite $\left(\mathrm{CuFe}_{2} \mathrm{~S}_{3}\right)$, were formed during bornite bioleaching, and a mass of elemental sulfur was formed in the late stage of bioleaching. The $\mathrm{Cu} 2 \mathrm{p}$ photoelectron spectrum revealed that $\mathrm{Cu}$ was present in the form of $\mathrm{Cu}$ (I) during the bornite bioleaching. Additionally, the $S 2 p_{3 / 2}$ photoelectron spectrum suggested that $\mathrm{S}^{2-}$ and $\mathrm{S}_{2}{ }^{2-}$ were gradually converted to $\mathrm{S}_{\mathrm{n}}{ }^{2-} / \mathrm{S}^{0}$, and the formation of elemental sulfur hindered the further dissolution of the bornite.
\end{abstract}

Keywords: bornite; A. caldus; L. ferriphilum; bioleaching; XRD; XPS

\section{Introduction}

Currently, the continuous consumption of high-grade copper resources is causing the grade of copper ore to decrease rapidly [1]. High energy consumption and environmental problems pose challenges to traditional pyrometallurgy and hydrometallurgy. Bioleaching has been widely used in leaching low grade copper ores and complex ores, with the advantages of a simple process, lower energy consumption, as well as being eco-friendly [2,3]. Nowadays, the main research focus of copper ore bioleaching is chalcopyrite, for the reserves of chalcopyrite are at the top of copper ore resource importance.

Bornite is also an important source of copper, following chalcopyrite and chalcocite in the list of copper resources [4]. Some researchers have studied the traditional hydrometallurgical process of bornite. The dissolution of bornite was divided into two steps in which bornite was leached in acidic ferric sulfate solution [5,6]. First, non-stoichiometric bornite was formed and second converted into chalcopyrite and elemental sulfur. Pesic [4] also had the same conclusion that the dissolution of bornite was divided into two steps during bornite leaching by acidic $\mathrm{FeCl}_{3}$. They suggested that the first step reaction was an electrochemical reaction controlled by a mixing kinetics process. The potential 
of the surface reaction was controlled by the $\mathrm{Cu}^{+}$in bornite crystal lattices and the first step was terminated when the $\mathrm{Cu}^{+}$in the bornite was consumed. Thereafter, the $\mathrm{Fe}^{3+}$ passed through the solution layer to reach the mineral surface and was reduced on the mineral surface, thereby $\mathrm{Cu}^{2+}$ was released. Buckley $[7,8]$ studied the surface changes of natural copper ore in long-term exposure to the environment by using X-ray photoelectron spectroscopy (XPS) and found that the surface of minerals oxidized quickly with hydrated iron oxide and copper-sulfur compounds forming on the surface. As exposure time increased, iron migrated to the surface to form ferrites, leaving copper-containing sulfides behind. During the surface rusting, ferrites separated on the mineral surface from the outside and formed a rugged coating on the surface of the copper-sulfur compounds. It was found that bornite transformed into $\mathrm{CuS}$ and $\mathrm{Cu}_{2} \mathrm{~S}$, and the iron element transformed into $\mathrm{Fe}(\mathrm{OH})_{3}$ or $\mathrm{FeS}$ on studying the electrochemical dissolution of bornite [9,10]. Moreover, during oxidative leaching of bornite with oxygen in $\mathrm{H}_{2} \mathrm{SO}_{4}, \mathrm{CuS}$ and $\mathrm{Cu}_{3} \mathrm{FeS}_{4}$ were formed [11]. Many researchers suggested that the chemical formula of the bornite can be expressed as $\left(\mathrm{Cu}_{3} \mathrm{FeS}_{4}\right)_{2} \cdot 2 \mathrm{Cu}^{+}$. During the dissolution process, $\mathrm{Cu}^{+}$ firstly transforms into $\mathrm{Cu}^{2+}$ and forms $\mathrm{Cu}_{3} \mathrm{FeS}_{4}$, although there is no direct evidence to prove the existence of $\mathrm{Cu}_{3} \mathrm{FeS}_{4}$.

In addition, some researches have been conducted on bornite bioleaching in recent years. Bevilaqua et al. [12,13] mainly used electrochemical testing methods to study bornite bioleaching. It was found that the presence of Acidithiobacillus ferrooxidans can accelerate the leaching of bornite. The fitting data of electrochemical impedance spectroscopy (EIS) displayed that a passivation film was formed on the surface of the bornite which was confirmed by cyclic voltammetry (CV) data. Wang [14] found that after 30 days of leaching with $A$. ferrooxidans, the copper extraction rate of bornite was $72.35 \%$ at $\mathrm{pH} 2.0$, initial $\mathrm{Fe}^{2+}$ concentration at $9 \mathrm{~g} / \mathrm{L}$, and pulp density at $5 \%$. Zhao et al. [15-17] mainly studied the mixed bioleaching process of bornite and chalcopyrite. The results showed that the presence of bornite could maintain the solution potential within a suitable range and thus accelerated the dissolution of chalcopyrite. At the same time, the galvanic effect between these two minerals also accelerated the dissolution process. Wang et al. [18] studied the bioleaching of mixed ore of bornite and pyrite by L. ferriphilum. It was found that the addition of pyrite in the mixed ore increased the copper extraction of bornite, which was related to the galvanic effect between them. Yang et al. [19] used XRD and XPS to characterize the intermediary species during bornite bioleaching by mixed moderately thermophilic culture, which suggested that bornite can be transformed into chalcocite, chalcopyrite, and covellite. Furthermore, Zhao [20] found that bornite tended to be directly oxidized to $\mathrm{CuS}, \mathrm{FeOOH}$, and $\mathrm{S}^{0}$ on the surface in bioleaching by using moderately thermophilic culture.

Overall, it is obvious that the dissolution mechanism of bornite is not fully resolved. For example, whether $\mathrm{CuS}, \mathrm{CuFeS}_{2}, \mathrm{Cu}_{3} \mathrm{FeS}_{4}$, and / or $\mathrm{Cu}_{2} \mathrm{~S}$ are intermediate species during bornite bioleaching, whether different kinds of bacteria have an influence on the production of different intermediates in the bornite bioleaching, and whether these intermediates are present at the same time are all open questions. In addition, no previous studies have further investigated bornite bioleaching by L. ferriphilum or A. caldus and the intermediate phase transformation during the process remains unclear. Therefore, this paper further investigates the above problems to improve knowledge on the dissolution mechanism of bornite.

\section{Materials and Methods}

\subsection{Minerals}

The bornite was collected from the Yushui copper mine in Meizhou, Guangdong, China. After grinding and sieving, the 200 mesh $(0.074 \mathrm{~mm})$ mineral was obtained for experiments. Chemical analysis conducted by X-ray fluorescence (parameters given in Section 2.5) showed that the bornite sample contained $(w / w) 62.30 \% \mathrm{Cu}, 10.03 \% \mathrm{Fe}$, and $21.76 \% \mathrm{~S}$ (Table 1). XRD results indicated that bornite was the main mineralogical component so the ore samples used in the study were of high purity (Figure 1). 


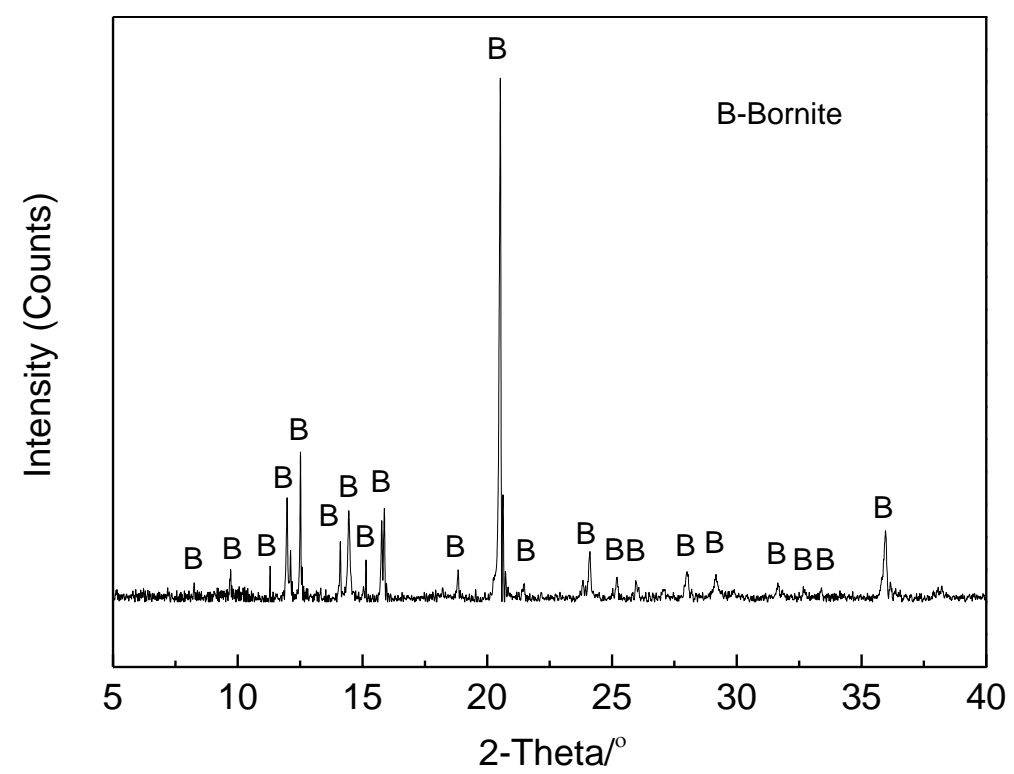

Figure 1. X-ray powder diffraction analysis of bornite.

Table 1. Chemical composition of the bornite.

\begin{tabular}{cccccccccc}
\hline Elements & $\mathbf{O}$ & $\mathbf{S i}$ & $\mathbf{S}$ & $\mathbf{F e}$ & $\mathbf{C u}$ & $\mathbf{Z n}$ & As & Ag & $\mathbf{P b}$ \\
\hline $\mathrm{Wt} \%$ & 2.91 & 0.63 & 21.76 & 10.03 & 62.30 & 0.15 & 0.15 & 1.35 & 0.47 \\
\hline
\end{tabular}

\subsection{Microorganisms}

L. ferriphilum and A. caldus are both moderately thermophilic bacteria which are more suitable to relatively high temperature than mesophiles and to high pulp density than extreme thermophilic bacteria [21]. L. ferriphilum and A. caldus used in this work were provided by the Key Lab of Biohydrometallurgy of Ministry of Education, Central South University, Changsha, China. L. ferriphilum and A. caldus were cultured both in $9 \mathrm{~K}$ medium containing $\left(\mathrm{NH}_{4}\right)_{2} \mathrm{SO}_{4}(3.00 \mathrm{~g} / \mathrm{L})$, $\mathrm{KCl}(0.10 \mathrm{~g} / \mathrm{L}), \mathrm{K}_{2} \mathrm{HPO}_{4}(0.50 \mathrm{~g} / \mathrm{L}), \mathrm{MgSO}_{4} \cdot 7 \mathrm{H}_{2} \mathrm{O}(0.50 \mathrm{~g} / \mathrm{L}), \mathrm{Ca}\left(\mathrm{NO}_{3}\right)_{2}(0.01 \mathrm{~g} / \mathrm{L})$ [22] at $45^{\circ} \mathrm{C}, 170$ $\mathrm{rpm}$, and $\mathrm{pH} 1.70$. The energy resources of $L$. ferriphilum and $A$. caldus were $\mathrm{FeSO}_{4} \cdot 7 \mathrm{H}_{2} \mathrm{O}(44.70 \mathrm{~g} / \mathrm{L})$ and $\mathrm{S}(10 \mathrm{~g} / \mathrm{L})$ respectively. The cell concentration was observed under a microscope every two days until it grew to the exponential growth stage with a cell concentration higher than $1.0 \times 10^{7}$ cells $/ \mathrm{mL}$. Then suspension containing cells were collected by centrifugation (Beckman Coulter, lnc. Avanti j-E) at $10,976 \times g$ and $4{ }^{\circ} \mathrm{C}$ for $20 \mathrm{~min}$, bacteria adhering on the centrifuge bottle wall were rinsed with $1 \mathrm{~mL}$ sterilized distilled water which was acidified by $20 \%(w / w)$ dilute sulfuric acid to $\mathrm{pH} 2.0$ and transferred into $10 \mathrm{~mL}$ centrifuge tubes. The cell concentration of the concentrated bacterial solution was higher than $1.0 \times 10^{8}$ cells $/ \mathrm{mL}$.

\subsection{Electrochemical Experiments}

Electrochemical experiments were conducted with a conventional three-electrode cell. Graphite rods were used as the counter electrode and an $\mathrm{Ag} / \mathrm{AgCl}(3.0 \mathrm{M} \mathrm{KCl})$ electrode as the reference electrode. Carbon paste electrodes were used as the working electrode, which was made by mixing $0.7 \mathrm{~g}$ minerals, $0.2 \mathrm{~g}$ graphite, and $0.1 \mathrm{~g}$ solid paraffin. The mixture was heated and stirred in a $50 \mathrm{~mL}$ beaker till the paraffin melted. After that the mixture was transferred rapidly into a tablet model for tableting under a pressure of $150 \mathrm{~kg} / \mathrm{cm}^{2}$ for three minutes, and then taken out for air drying. The electrodes were polished using 1200-grit silicon carbide paper to obtain a smooth surface before electrochemical measurements. 
The electrolyte used in the experiments was $9 \mathrm{~K}$ medium. The $\mathrm{pH}$ of the solution was adjusted to 1.70 with $20 \%(w / w)$ dilute sulfuric acid. Nitrogen gas was sparged 15 min before and during the electrochemical measurements to remove dissolved oxygen from the electrolyte.

All electrochemical experiments in this paper were performed with a Princeton Model 283 potentiostat (EG \& G of Princeton Applied Research) coupled to a personal computer. Cyclic voltammetry $(\mathrm{CV})$ tests were conducted at a sweep rate of $20 \mathrm{mV} / \mathrm{s}$ and potentiostatic polarization tests were performed for $1200 \mathrm{~s}$. All potentials in this paper are against an $\mathrm{Ag} / \mathrm{AgCl}$ electrode (3.0 $\mathrm{M} \mathrm{KCl).}$

\subsection{Bioleaching Experiments}

Bioleaching experiments were carried out in $250 \mathrm{~mL}$ Erlenmeyer flasks containing $100 \mathrm{~mL}$ of $9 \mathrm{~K}$ medium and $2 \mathrm{~g}$ of bornite. The initial cell concentration in the solution was controlled at about $1.0 \times 10^{7}$ cells $/ \mathrm{mL}$ by adding $1 \mathrm{~mL}$ of the concentrated bacterial solution. The temperature and $\mathrm{rpm}$ were set at $45^{\circ} \mathrm{C}$ and $170 \mathrm{r} / \mathrm{min}$, respectively. The $\mathrm{pH}$ was adjusted to $1.70 \pm 0.02$ with $20 \%$ ( $\left.w / w\right)$ dilute sulfuric acid when the $\mathrm{pH}$ of solution was higher than 1.70. The evaporation loss was compensated for periodically by adding distilled water. After the leaching experiments, the solution was filtered through a neutral filter paper, and the filter residues were washed 3 times with distilled water having a $\mathrm{pH}$ of 1.70 . After drying in a vacuum drying oven at normal temperature for $24 \mathrm{~h}$, the dried filter residues were subjected to the corresponding tests.

\subsection{Analytical Methods}

Chemical analysis was conducted by X-ray fluorescence, using an X-ray fluorescence S4 Explorer spectrometer (Bruker AXS, Germany). The X-ray tube (Rh tube with a $75 \mu \mathrm{m}$ window) was set at $40 \mathrm{kV}$ and $15 \mathrm{~mA}$ and the sample powder was scanned over the range of $5-85^{\circ}$. The copper concentrations were analyzed by inductively coupled plasma-atomic emission spectrometry (ICP-AES) (America Baird Co. PS-6). The XRD analysis of mineral samples was performed by a Bruker D8 Advance X-Ray diffractometer $(\mathrm{Cu} \mathrm{K} \alpha, \lambda=1.5406 \AA)$ with an operating voltage of $40 \mathrm{kV}$, temperature of $25^{\circ} \mathrm{C}$, current of $40 \mathrm{~mA}$, steps of $0.004^{\circ}$, and a step time of $28.5 \mathrm{~s}$. The XPS analyses of the mineral samples were performed by a Thermo Fisher Scientific ESCALAB 250Xi photoelectron spectrometer. The light source was a monochromatic Al excitation source $(1486.6 \mathrm{eV})$ with a power of $200 \mathrm{~W}$, a pass energy of $20 \mathrm{eV}$, a step size of $0.1 \mathrm{eV}$, and a vacuum of less than $1 \times 10^{-9}$ mbar. Calibration was using the $\mathrm{C} 1 \mathrm{~s}$ binding energy at $284.6 \mathrm{eV}$. Due to spin-orbit splitting, the $2 \mathrm{p}$ peak of $\mathrm{S}$ existed in the form of a double peak ( $S 2 p_{3 / 2}$ and $S 2 p_{1 / 2}$ ), and the peak intensity of $S 2 p_{3 / 2}$ was twice the intensity of the $\mathrm{S} 2 \mathrm{p}_{1 / 2}$ peak. The binding energy of $\mathrm{S} 2 \mathrm{p}_{1 / 2}$ peak is $1.19 \mathrm{eV}$ higher than that of the $\mathrm{S} 2 \mathrm{p}_{3 / 2}$ peak. The Gaussian-Lorentzian (SGL) function was used for fitting with a $50 \%$ Gaussian function and a $50 \%$ Lorentzian function. The background fitting was performed using the Shirley method. To simplify the graph, only the $S 2 p_{3 / 2}$ peak is shown in the figures.

\subsection{Calculation of Acid Consumption}

The total consumption of acid during the leaching of bornite was calculated by Equation (1) [23].

$$
\mathrm{N}=\left(10^{-a}-10^{-b}\right) \times 1000 \times \mathrm{V} \div \mathrm{M}
$$

where $\mathrm{N}$ is the consumption of $\mathrm{H}^{+}$for per gram of ore, with units of $\mathrm{mmol} / \mathrm{g}$, a is the $\mathrm{pH}$ value measured on the previous day (measured after adding sulfuric acid), $b$ is the $\mathrm{pH}$ value measured on the following day (measured before adding sulfuric acid), V is the volume of leaching solution, with units of $\mathrm{L}$ and $\mathrm{M}$ is the weight of added minerals, with units of $\mathrm{g}$. 


\section{Results and Discussion}

\subsection{Electrochemical Experiments}

\subsubsection{Potentiostatic Polarization Experiments}

The potentiostatic polarization tests were mainly used to describe the strength of the surface reaction of the electrode and the redox properties of the surface reaction. Figure 2 shows the relationship between total charge (calculated based on the integrals from the current-time curves of bornite electrode) and the applied potential at $\mathrm{pH}$ at 1.0, 1.5, and 3.0. It can be seen that the oxidation region and reduction region of bornite at the above three $\mathrm{pH}$ conditions are similar, with the same critical point at $200 \mathrm{mV}$. This suggests that the difference of $\mathrm{pH}$ cannot change the principle reaction of bornite during bioleaching. The bornite tends to be directly oxidized when the redox potential is higher than $200 \mathrm{mV}$ and to be reduced when the redox potential is less than $200 \mathrm{mV}$. In addition, the slopes of the curves in the oxidation region and reduction region increase as the $\mathrm{pH}$ increases, which suggests that bornite is easier to be oxidized at lower $\mathrm{pH}$. Therefore, the $\mathrm{pH}$ of the solution is the main step to limit the leaching of bornite.

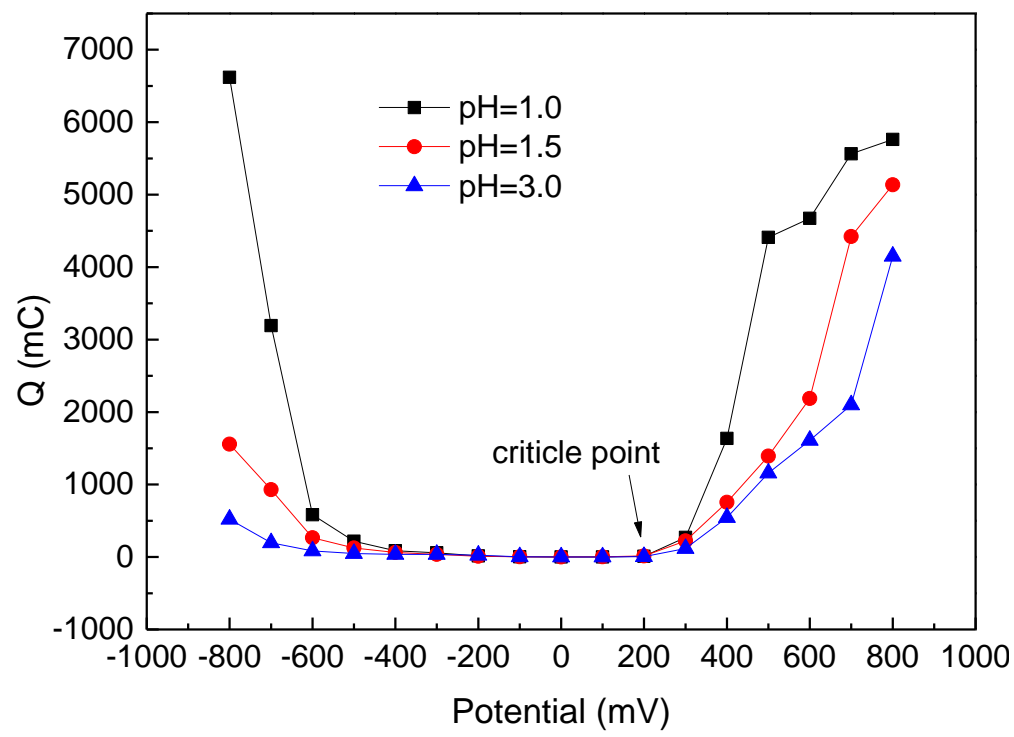

Figure 2. Relationship between total charge and applied potential at $\mathrm{pHs}$ of 1.0, 1.5, and 3.0.

\subsubsection{Cyclic Voltammetry Measurements}

Cyclic voltammetry measurements of bornite electrodes at different $\mathrm{pH}$ in $9 \mathrm{~K}$ media were carried out by the positive scan route. The positive scan route, scanning twice in total, started scanning from $200 \mathrm{mV}$ to $800 \mathrm{mV}$, then reversed to $-800 \mathrm{mV}$, and finally switched towards the anodic direction again. The result is shown in Figure 3. Few anodic and cathodic current peaks are observed with the bornite electrode at $\mathrm{pH}$ 3.0, however, five distinct peaks are detected in the other two curves. It is obvious that bornite hardly reacts at this $\mathrm{pH}$. This is consistent with the conclusion from Figure 2. The reaction indicated by the anodic peak a, is related to the oxidation of copper as reported in the literature [15]. Peak b appears in the potential range of $600 \mathrm{mV}$ to $800 \mathrm{mV}$, which is an indication of the formation of covellite $[24,25]$. The first cathodic peak c represents the reduction of covellite formed during the oxidation of bornite $[9,15]$. The cathodic peaks $\mathrm{d}$ and peak e are considered to be the reduction of covellite or bornite and copper (I) to metallic copper, respectively [13].

Additionally, it is clear that each peak of the bornite electrode at $\mathrm{pH} 1.0$ is higher than at $\mathrm{pH} 1.5$, which means the high $\mathrm{pH}$ value of solution will hinder the oxidation of bornite. On this basis, considering the optimum $\mathrm{pH}$ range of the bacteria growth, the following bioleaching experiments were carried out. 


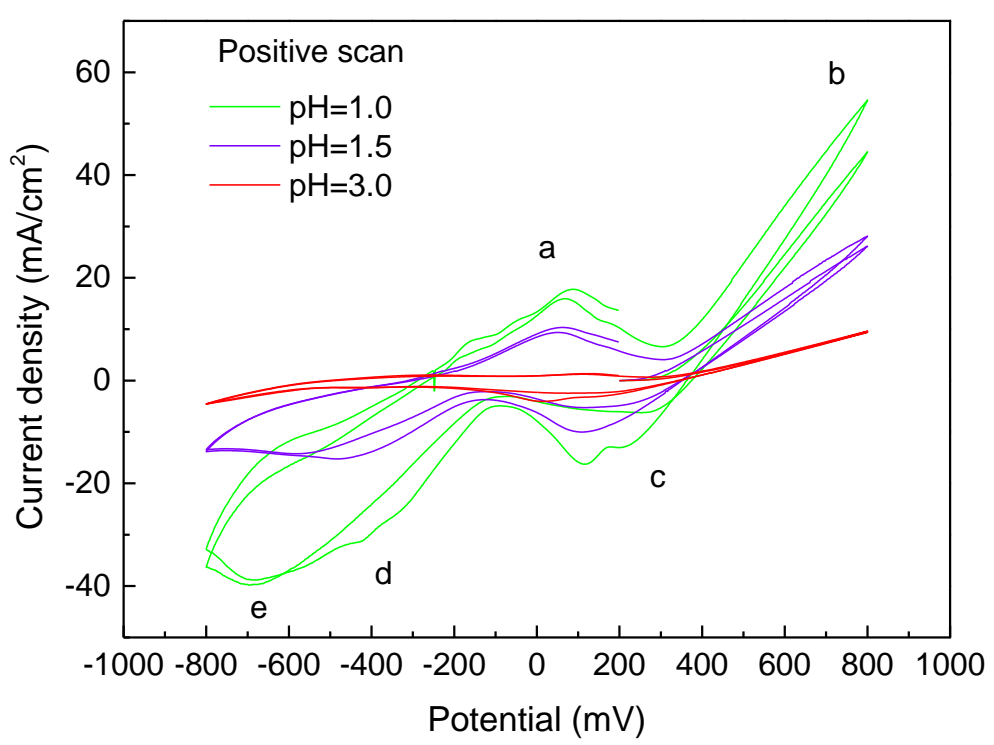

Figure 3. Cyclic voltammetry spectra of the bornite electrode at different $\mathrm{pHs}$.

\subsection{Bioleaching Experiments}

Figure 4 shows the variations of $\mathrm{pH}$ during bornite bioleaching by L. ferriphilum, A. caldus, and the sterile control. The $\mathrm{pH}$ of the sterile control solution rises every day for the first 14 days of leaching. The $\mathrm{pH}$ begins to decrease from day 14 to day 21, and then the previous changes are restored. Variation of $\mathrm{pH}$ in the presence of L. ferriphilum is similar to the sterile control, except that the degree of change is more intense. It indicates that the presence of L. ferriphilum cannot change the oxidation principle of bornite. However, the variation of $\mathrm{pH}$ in the presence of $A$. caldus is significantly different from the behavior at the above two conditions. The $\mathrm{pH}$ rises only in the first three days then is lowered to a very low level at about $\mathrm{pH} 1.0$ in the initial stage of leaching. It may relate to the oxidation of sulfur-containing compounds that cause a rapid decrease in $\mathrm{pH}$ of the solution. Therefore the presence of $A$. caldus may accelerate the leaching of bornite more in the initial stage of bornite leaching than that in the cases of L. ferriphilum and sterile control. After that, the rise of $\mathrm{pH}$ is slow and after 20 days, the variation is similar to the former two conditions.

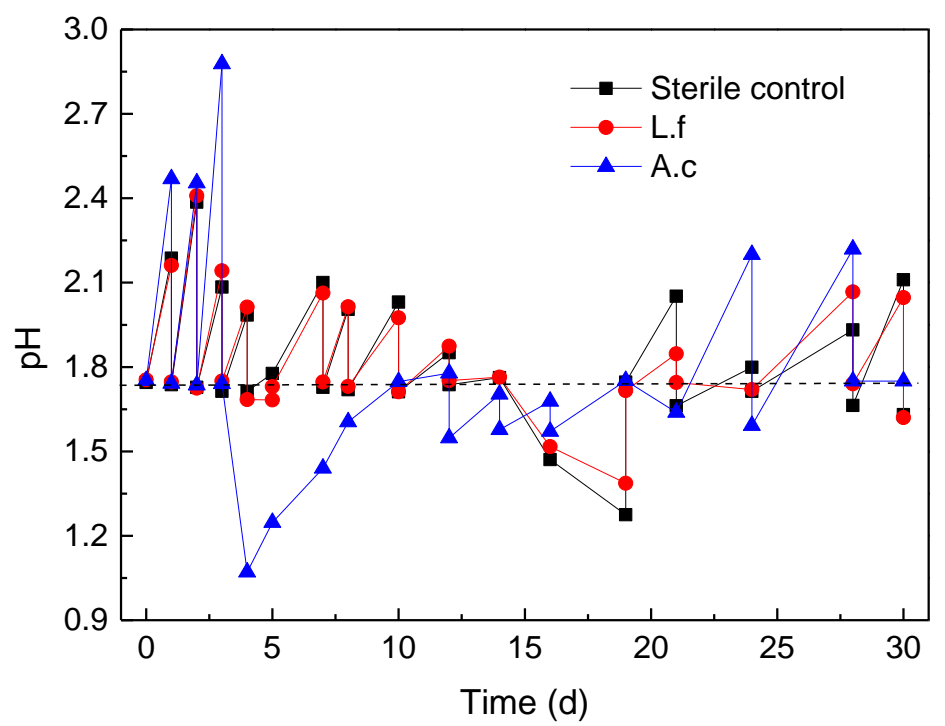

Figure 4. Variations of $\mathrm{pH}$ during bornite bioleaching by L. ferriphilum, A. caldus, and sterile control. 
The total acid consumption of L. ferriphilum, A. caldus and the sterile control during bornite bioleaching is shown in Figure 5, which indicates that the dissolution of bornite is acid-consuming and the reaction is shown in Equation (2) [26]:

$$
4 \mathrm{Cu}_{5} \mathrm{FeS}_{4}+37 \mathrm{O}_{2}+20 \mathrm{H}^{+} \rightarrow 20 \mathrm{Cu}^{2+}+4 \mathrm{Fe}^{3+}+16 \mathrm{SO}_{4}^{2-}+10 \mathrm{H}_{2} \mathrm{O}
$$

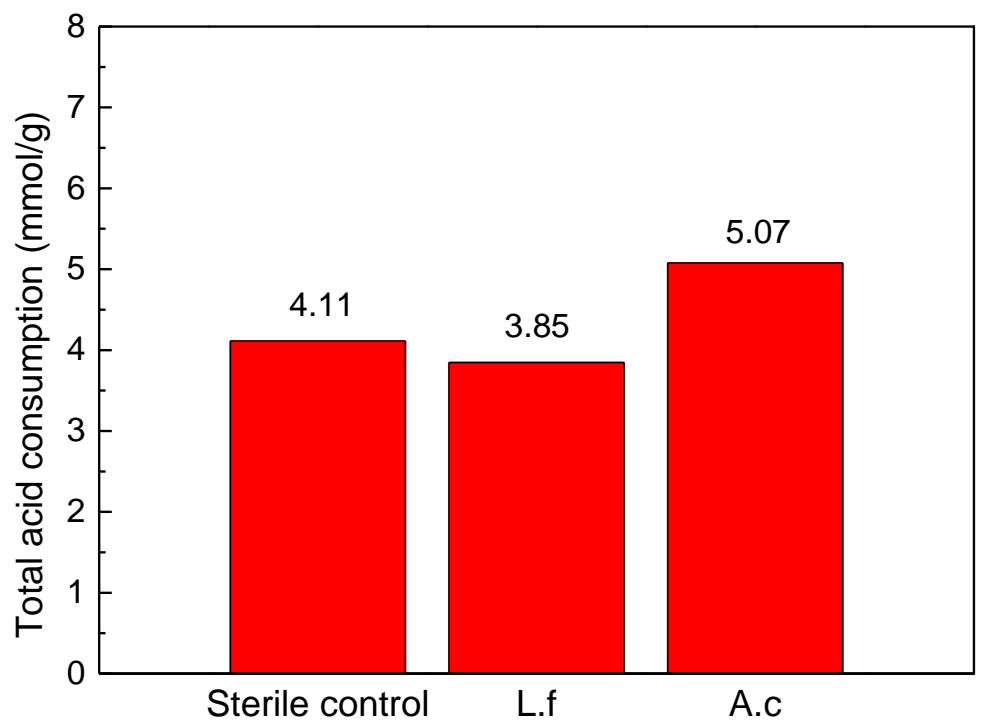

Figure 5. Total acid consumption of L. ferriphilum, A. caldus and sterile control during bornite bioleaching.

The result of total acid consumption of L. ferriphilum is close to the sterile control while the total acid consumption of $A$. caldus is slightly higher than the sterile control.

Figure 6 shows the variations in the copper extraction rate during bornite bioleaching. During the whole leaching process, the copper extraction of bornite by L. ferriphilum and A. caldus is significantly higher than that by the sterile control. After leaching for 25 days, the copper extraction rate of the bacteria group reaches a maximum of about $70 \%$, while the sterile control is only $36 \%$ after 30 days. It can be seen that the presence of L. ferriphilum and A. caldus significantly accelerates the bornite leaching process. The copper extraction rate of the sterile control increases rapidly in the first five days, reaching 15\%, and then the growth becomes slow. However, the copper extraction rate of the bacteria group increases rapidly until around the 15th day. Although the final copper extraction rate of the bornite is similar in the presence of L. ferriphilum and A. caldus, in the latter it rises faster in the early stage of leaching. This is in line with the result of $\mathrm{pH}$ variation in the bornite bioleaching at the early stage by A. caldus (Figure 4).

L. ferriphilum mainly plays the role of oxidizing $\mathrm{Fe}^{2+}$ and producing $\mathrm{Fe}^{3+}$ during the leaching process. The $\mathrm{Fe}^{3+}$ as an efficient oxidant accelerates the leaching process of the bornite, as shown in the following equation $[4,13]$.

$$
\begin{gathered}
\mathrm{Cu}_{5} \mathrm{FeS}_{4}+12 \mathrm{Fe}^{3+} \rightarrow 5 \mathrm{Cu}^{2+}+13 \mathrm{Fe}^{2+}+4 \mathrm{~S}^{0} \\
\mathrm{Fe}^{2+} \stackrel{\text { L. ferriphilum }}{\longrightarrow} \mathrm{Fe}^{3+}
\end{gathered}
$$

The main role of $A$. caldus is to convert sulfur to sulfate as reported by Gu et al. [27] and the equation is shown below.

$$
\mathrm{S}+\frac{3}{2} \mathrm{O}_{2}+\mathrm{H}_{2} \mathrm{O} \stackrel{\text { A. caldus }}{\longrightarrow} \mathrm{H}_{2} \mathrm{SO}_{4}
$$




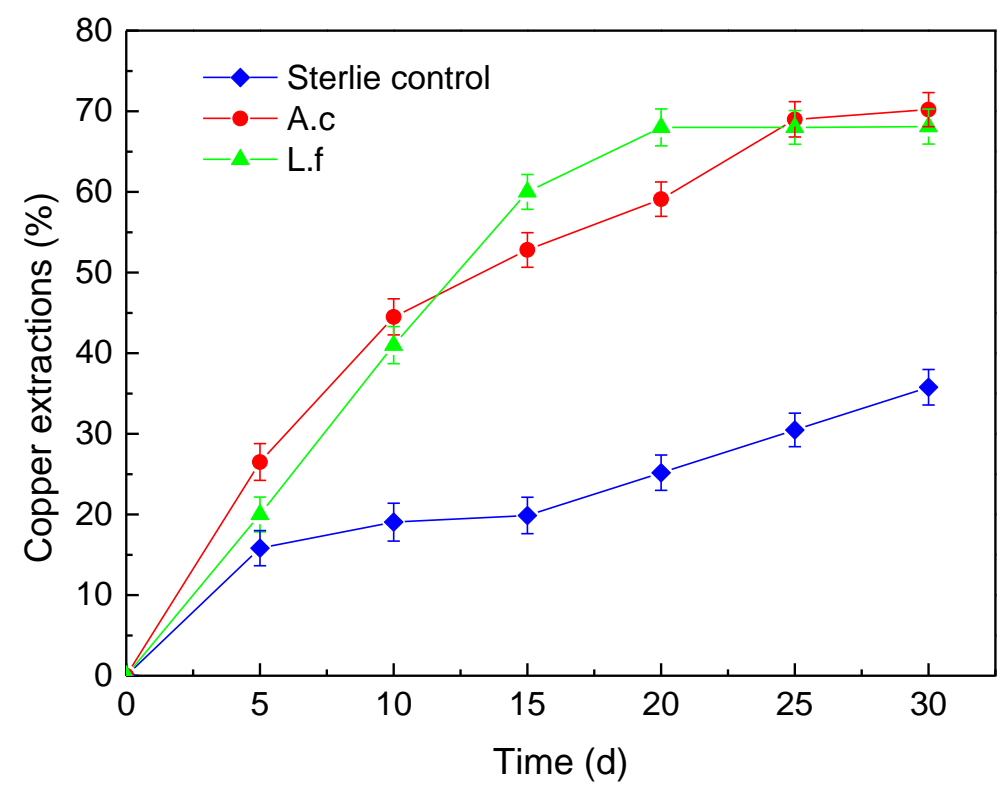

Figure 6. Variations of copper extraction rate during bioleaching.

\subsection{X-ray Powder Diffraction Analysis}

Figure 7 shows the $\mathrm{X}$-ray powder diffraction analysis of bornite leached residues by L. ferriphilum. In the early stage of leaching, the peaks of covellite (CuS, PDF\#78-2121) and mooihoekit (Cu9Fe9S16, PDF\#27-0165) are detected in the XRD pattern. Actually, the diffraction peaks of covellite and mooihoekit both fitted well to the leached residues because their crystal parameters are very similar. The results suggest that the dissolution of bornite is easily converted into a non-stoichiometric ratio of copper iron sulfide in the early stage of bioleaching. Some previous studies reported that covellite coating was also found in the early stage of leaching during a hydrometallurgical process of bornite [11]. However, some CuS peaks can still be observed in the late stage of leaching, which may relate to the mutual conversion of $\mathrm{CuS}$ and other copper iron sulfide intermediates. Then mooihoekit transforms into isocubanite $\left(\mathrm{CuFe}_{2} \mathrm{~S}_{3}, \mathrm{PDF} 27-0166\right)$, as peaks of isocubanite are observed from the 12th day as the reaction proceeds. Wang et al. [18] also obtained a similar conclusion when studying the effect of pyrite on bornite bioleaching. Then the characteristic peaks of elemental sulfur (S8, PDF\#74-1465) are clearly observed on the 16th day. The number of elemental sulfur peaks gradually increases until the end of leaching. In combination with the phenomenon that the copper extraction rate of bornite in the presence of L. ferriphilum becomes slow after the 15th day (Figure 6), it can be considered that the occurrence of elemental sulfur may cause passivation of the bornite. The phenomenon of passivation in bioleaching is widespread, not only in laboratory experiments but also in industrial production such as in recovering the metals from a complex waste matrix or solid wastes using bioleaching $[28,29]$. It was generally believed that elemental sulfur formed and covered the surface of the minerals or secondary resources, which stopped further reaction. Taking chalcopyrite leaching as an example, it was observed that an impervious sulfur layer formed on the surface of chalcopyrite which reduced the contact of bacteria or reactants with minerals [30-32]. Moreover, the passivation layer functioned as a capacitor, which made the diffusion of molecules and ions to and from the mineral surface difficult [33]. In a word, the formation of a passivation layer will reduce the extraction. Therefore, some researchers made studies on depassivation $[34,35]$, in order to improve the metallic extraction. In any case, the problem, including the specific passivation mechanism and the method of depassivation, is worthy of further consideration. 


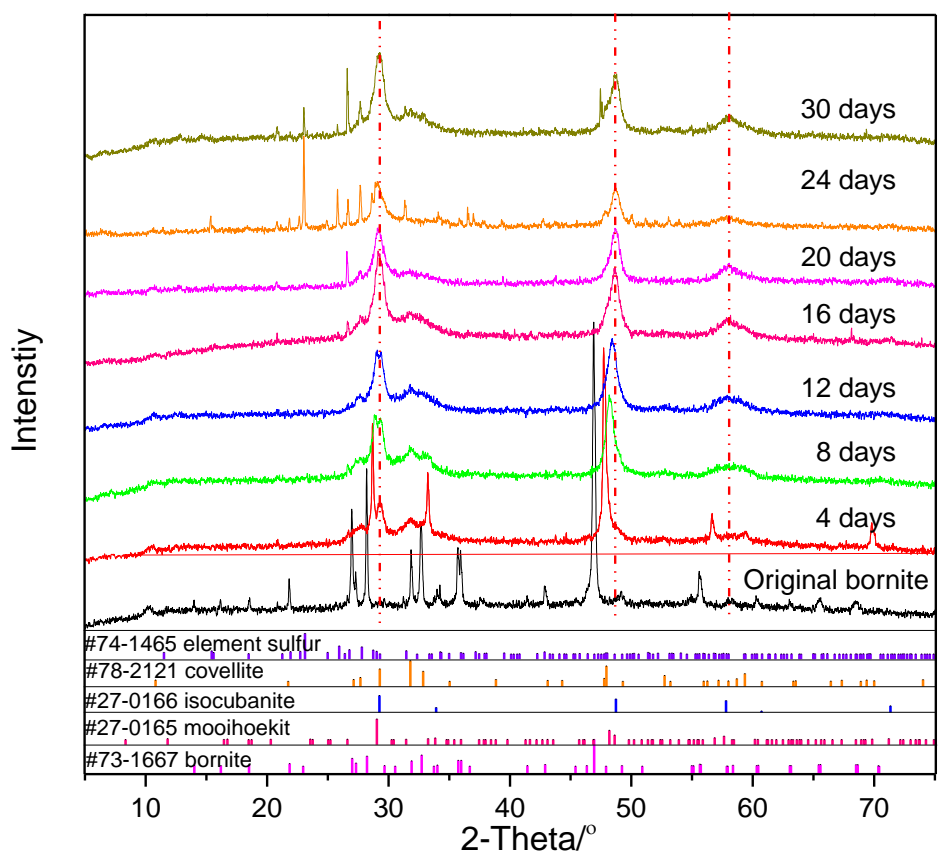

Figure 7. X-ray powder diffraction analysis of leached residues by L. ferriphilum.

X-ray powder diffraction analyses of bornite leached residues by A. caldus are shown in Figure 8. It can be seen that the intermediates of bornite during bioleaching in the presence of $A$. caldus are the same as in the presence of L. ferriphilum. It is notable that the intermediate species of bornite bioleaching by these two bacteria are similar. The difference between them is that the elemental sulfur of the latter one appears earlier, and the peaks of elemental sulfur are observed on the fourth day. The result is consistent with the conclusion of a faster leaching speed of bornite dissolution by A. caldus in the early stage of bioleaching (Figure 6).

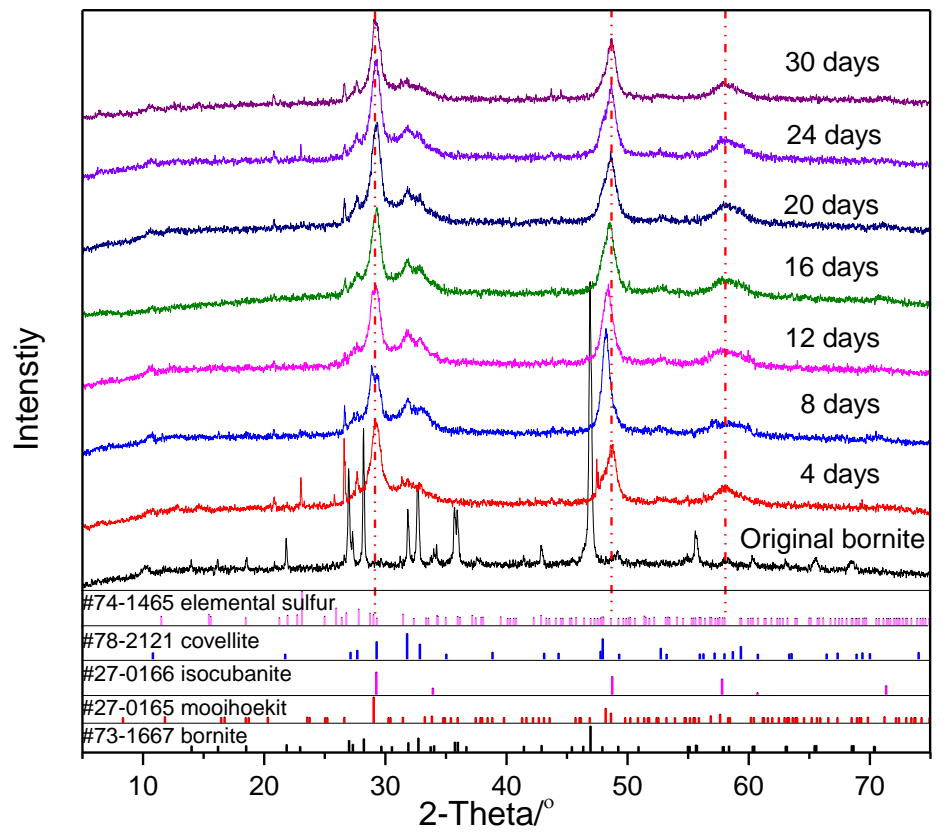

Figure 8. X-ray powder diffraction analysis leached residues by A. caldus.

Therefore, according to the results of the XRD patterns (Figures 7 and 8), it is considered that the dissolution process of the bornite is: $\mathrm{Cu}_{5} \mathrm{FeS}_{4} \rightarrow \mathrm{Cu}_{9} \mathrm{Fe}_{9} \mathrm{~S}_{16} \rightarrow \mathrm{CuFe}_{2} \mathrm{~S}_{3} \rightarrow \mathrm{CuS} \rightarrow \mathrm{Cu}^{2+}$, which agrees with the conclusion of Wang [18]. Considering that these two kinds of bacteria have similar 
intermediate species during bornite bioleaching, the following XPS analysis of bornite residues leached by L. ferriphilum was performed.

\subsection{X-ray Photoelectron Spectroscopy Analysis}

The $\mathrm{Cu} 2 \mathrm{p}_{3 / 2}$ peak of the bornite is located at $932.4 \mathrm{eV}$, the $\mathrm{Cu} 2 \mathrm{p}_{1 / 2}$ peak is at $952.3 \mathrm{eV}$, and there is no satellite peak between 940 and $950 \mathrm{eV}$ (Figure 9a), which indicates that $\mathrm{Cu}$ in the bornite exists in the form of $\mathrm{Cu}$ (I) not $\mathrm{Cu}$ (II) $[15,36]$. On the 7th day and the 21st day of leaching, the $\mathrm{Cu}$ $2 \mathrm{p}$ peak position and the bimodal spacing in the leached residues remain substantially unchanged, which suggests that $\mathrm{Cu}$ is also present in the form of $\mathrm{Cu}$ (I) during leaching. The $\mathrm{Cu} 2 \mathrm{p}_{3 / 2}$ peak at 932.4 eV represents $\mathrm{CuS}$ [37], which means $\mathrm{Cu} 2 \mathrm{p}_{3 / 2}$ peaks in the leached residues on day 7 and 21 are all derived from $\mathrm{CuS}$, which is consistent with the CuS appearing in the XRD pattern. The Cu LMM peak of the ore is located at $569.2 \mathrm{eV}$ (Figure 9b). On the 7th and 21st day, the Cu LMM peaks of the leached residues are located at $568.9 \mathrm{eV}$ and $568.5 \mathrm{eV}$, respectively, which is also consistent with the binding energy value $(568.5 \mathrm{eV})$ of the previously reported CuS LMM peak $[20,38,39]$.
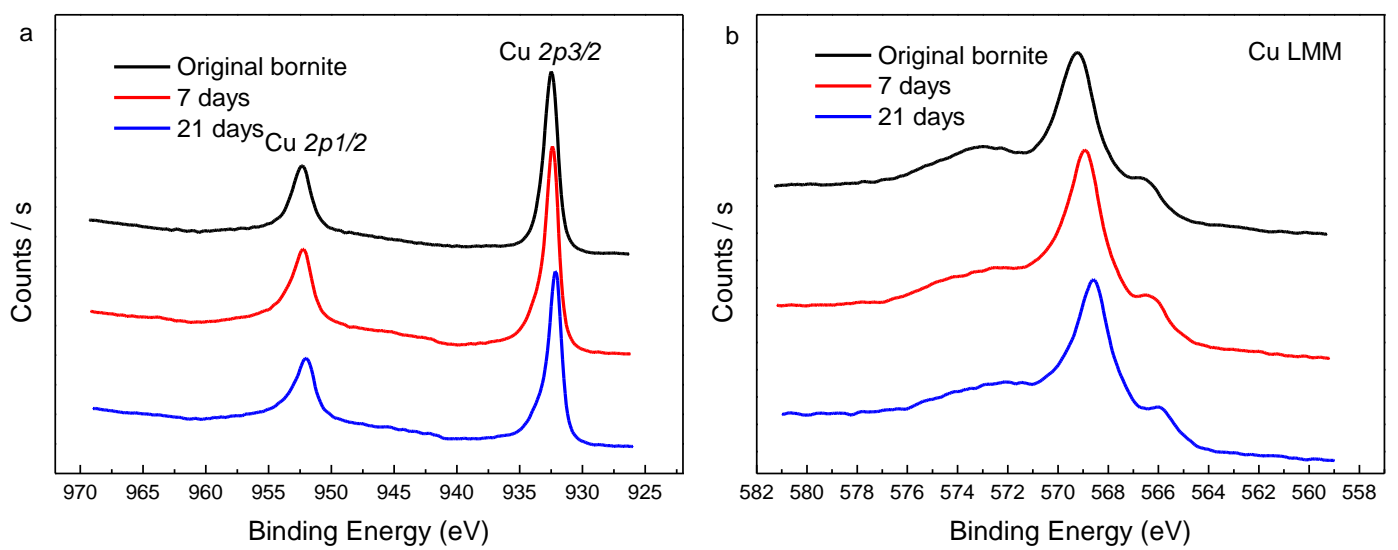

Figure 9. Cu 2p XPS spectra (a) and Cu LMM XPS spectra (b) of bornite residues after bioleaching for 7 days and 21 days.

The $\mathrm{S} 2 \mathrm{p}_{3 / 2}$ XPS spectra of original bornite, and of leached residues at 7 days and 21 days are shown in Figure 10. The strongest $S 2 p_{3 / 2}$ peak in the initial bornite is located at $161.4 \mathrm{eV}$, representing $\mathrm{S}^{2-}$ in the bornite bulk, and the location of the $\mathrm{S}^{2-}$ peak is slightly different from the results reported at $161.8 \mathrm{eV}$ by Harmer and Acres et al. [40,41]. The fitting results of Harmer and Acres et al. showed a small $S^{2-} 2 p_{3 / 2}$ peak at $160.1 \mathrm{eV}$ at the bornite surface. It can be seen that the fitting is not good when fitting the surface layer $\mathrm{S}^{2-}$ separately. So two kinds of $\mathrm{S}^{2-}$ are not distinguished in this paper, which is consistent with the work of Harmer and Acres et al. [40,42]. The elemental sulfur $2 \mathrm{p}_{3 / 2}$ peak is over a wide range (163.05-164.7 eV), and the polysulfide was also reported over a wide range (163.0-163.9 eV) [37]. Moreover, polysulfides have a variety of species with different chain lengths, and it is difficult to achieve a differentiating fit [36], therefore, the elemental sulfur and polysulfide were combined in the range (163.0-164.7 eV) for fitting.

Figure 11 shows the compositions of sulfur species of bornite leached by L. ferriphilum for 7 days, and 21 days. The content of $S_{n}{ }^{2-} / S_{0}$ in the original bornite is $13.53 \%$, and the content of $S_{n}{ }^{2-} / S_{0}$ after leaching for 7 days and 21 days is $44.88 \%$ and $50.00 \%$, respectively. The substance with a peak at $162.3-162.4 \mathrm{eV}$ is $\mathrm{S}_{2}{ }^{2-}$ [37]. It can be found that the original bornite contains $23.37 \%$ of $\mathrm{S}_{2}{ }^{2-}$. After 7 days of leaching, the content of $\mathrm{S}_{2}{ }^{2-}$ is $30.97 \%$ and $29.78 \%$ after 21 days of leaching. It can be seen from the variation of sulfur species contents that $\mathrm{S}^{2-}$ and $\mathrm{S}_{2}{ }^{2-}$ are gradually transformed into $\mathrm{S}_{\mathrm{n}}{ }^{2-} / \mathrm{S}^{0}$ during bornite bioleaching. $\mathrm{S}_{2} \mathrm{O}_{3}{ }^{2-}$ is not found in the fitting results, indicating that the sulfur metabolism pathway of bornite in the presence of L. ferriphilum is mainly the polysulfide pathway. The leached residues were washed three times with distilled water with a $\mathrm{pH}$ of 1.70 , and $\mathrm{SO}_{4}{ }^{2-}$ was mainly derived from jarosite [43]. On the 7 th day and the 21 st day of leaching, $\mathrm{SO}_{4}{ }^{2-}$ in the leached 
residues is only about $5 \%$, indicating that there is only a small amount of jarosite formed. However, few peaks of jarosite are observed in the XRD pattern, perhaps because of the relatively low content of jarosite. Therefore, the formation of elemental sulfur is the main reason for passivation in the last stage of bioleaching.
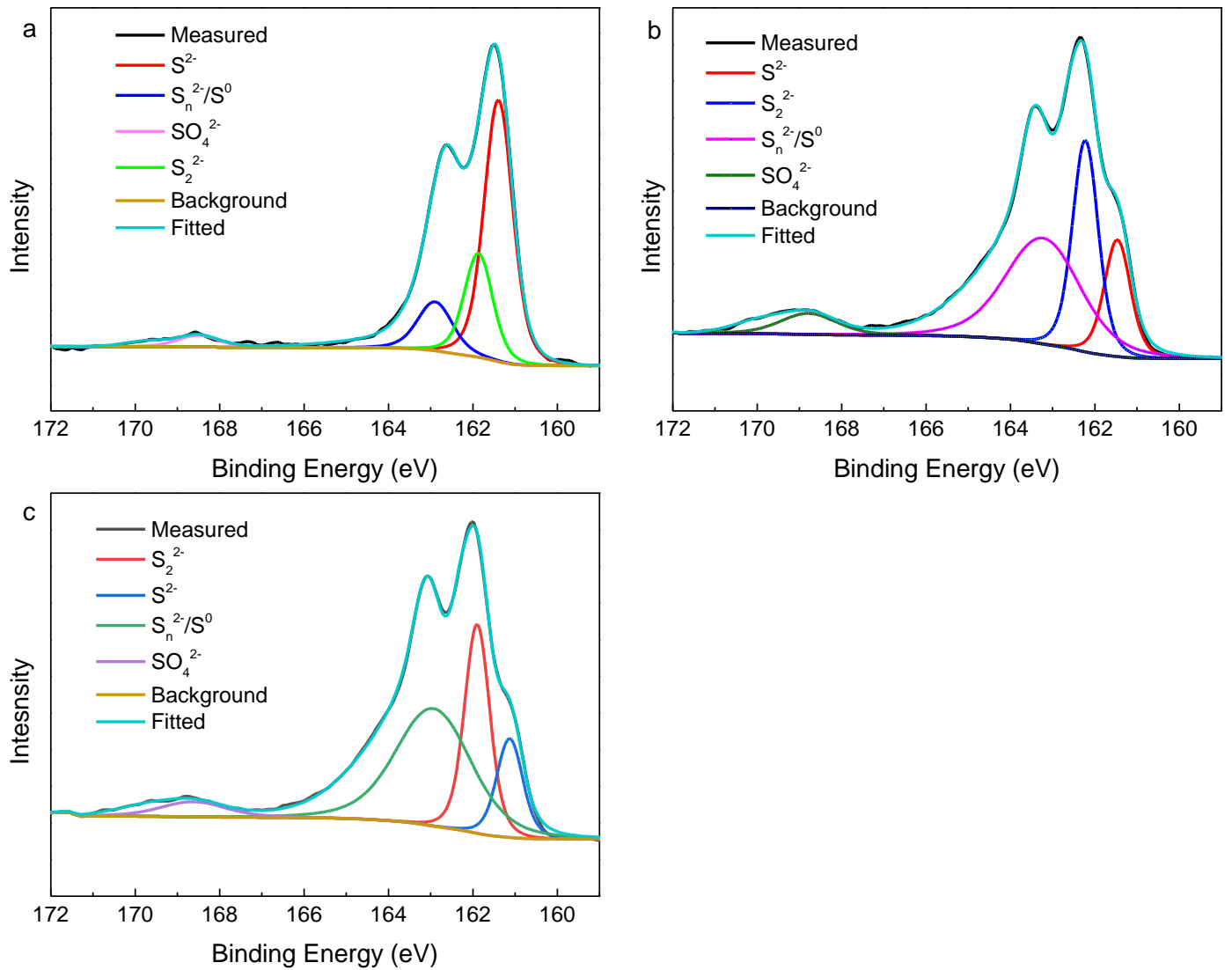

Figure 10. $S 2 p_{3 / 2}$ XPS spectra of original bornite (a) and leached residues: (b) 7 days and (c) 21 days.

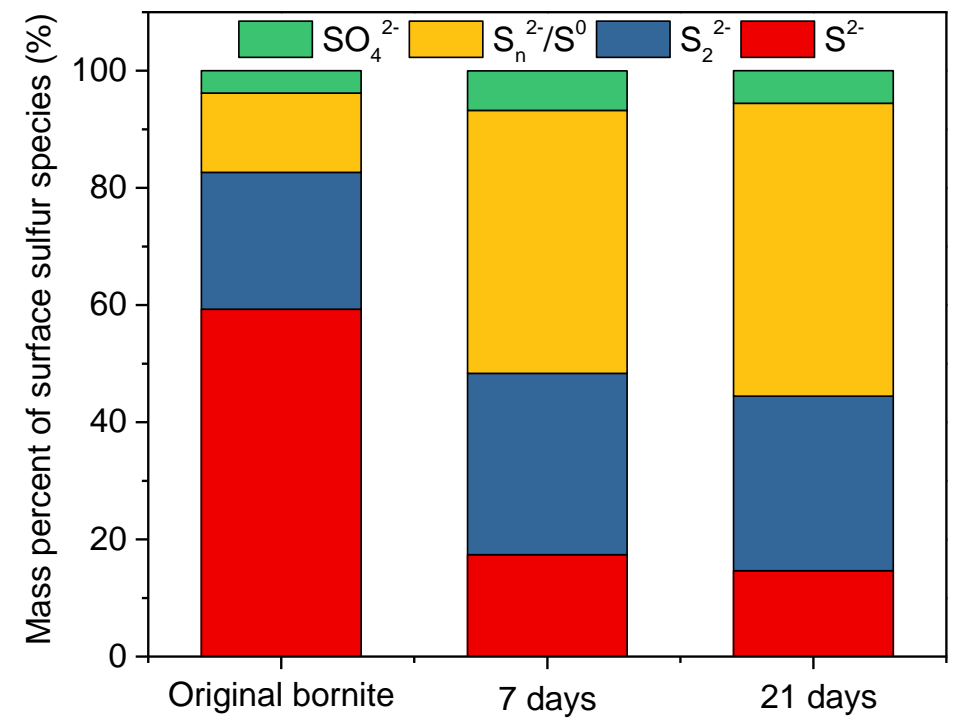

Figure 11. Compositions of sulfur species of bornite leached by L. ferriphilum at 7 days and 21 days. 


\section{Conclusions}

The results of bioleaching experiments and electrochemical experiments indicated that the dissolution of bornite was an acid-consuming process. Compared with the sterile control, the presence of L. ferriphilum and A. caldus significantly accelerated the leaching of bornite. The maximum copper extraction rate of the bornite bioleaching by L. ferriphilum and A. caldus was similar at about $70 \%$. XRD results showed that with the bornite bioleaching by L. ferriphilum or A. caldus, a large amount of mooihoekit $\left(\mathrm{Cu}_{9} \mathrm{Fe}_{9} \mathrm{~S}_{16}\right)$ and covellite $(\mathrm{CuS})$ were produced in the early stage of bioleaching. Moreover, isocubanite $\left(\mathrm{CuFe}_{2} \mathrm{~S}_{3}\right)$ that might be converted from mooihoekit $\left(\mathrm{Cu}_{9} \mathrm{Fe}_{9} \mathrm{~S}_{16}\right)$ was observed on the 12th day. The X-ray photoelectron spectrum of the leached residues revealed that $\mathrm{Cu}$ was present in the form of $\mathrm{Cu}$ (I) during the bornite bioleaching. Additionally, the $\mathrm{S} 2 \mathrm{p}_{3 / 2}$ photoelectron spectrum suggested that $\mathrm{S}^{2-}$ and $\mathrm{S}_{2}{ }^{2-}$ were gradually converted to $\mathrm{S}_{\mathrm{n}}{ }^{2-} / \mathrm{S}^{0}$, so the formation of elemental sulfur may hinder the further dissolution of the bornite.

Author Contributions: The experiments were conceived and designed by M.H., G.Q. and J.W.; The experiments were performed by M.H., R.L. and X.H.; The data was analyzed by M.H. and X.W.; J.W. and G.Q. contributed reagents/materials/analysis tools; The paper was written by M.H.; M.H., X.W., J.W., L.W. and C.F. improved and revised the paper.

Funding: This work was supported by the National Science Foundation of Hunan Province (No. 2018JJ1041), National Natural Science Foundation of China (No. 51774332, 51704331 and 51374248), Hunan Provincial Innovation Foundation for Postgraduate (No. CX2018B065) and Fundamental Research Funds for the Central Universities of Central South University (No. 2018zzts765). The authors thank beamline BL14B1 (Shanghai Synchrotron Radiation Facility) for providing the beam time and helps during experiments.

Conflicts of Interest: The authors declare no conflict of interest.

\section{References}

1. Norgate, T.; Jahanshahi, S. Low grade ores-Smelt, leach or concentrate? Miner. Eng. 2010, $23,65-73$. [CrossRef]

2. Debaraj, M.; Kim, D.J.; Ahn, J.G.; Rhee, Y.H. Bioleaching A microbial process of metal recovery A review. Metals Mater. Int. 2005, 11, 249-256.

3. Donati, E.R.; Sand, W. Microbial Processing of Metal Sulfides; Springer: Berlin/Heidelberg, Germany, 2007; Volume 130.

4. Pesic, B.; Olson, F.A. Leaching of bornite in acidified ferric chloride solutions. Metall. Trans. B 1983, 14, 577-588. [CrossRef]

5. Dutrizac, J.E.; Macdonald, R.J.C.; Ingraham, T.R. The kinetics of dissolution of bornite in acidified ferric sulfate solutions. Metall. Trans. 1970, 1, 225-231. [CrossRef]

6. Dutrizac, J.E.; MacDonald, R.J.C.; Ingraham, T.R. Effect of pyrite, chalcopyrite and digenite on rate of bornite dissolution in acidic ferric sulphate solutions. Can. Metall. Q. 1971, 10, 3-7. [CrossRef]

7. Buckley, A.; Woods, R. X-ray photoelectron spectroscopic investigation of the tarnishing of bornite. Aust. J. Chem. 1983, 36, 1793-1804. [CrossRef]

8. Buckley, A.N.; Hamilton, I.C.; Woods, R. Investigation of the surface oxidation of bornite by linear potential sweep voltammetry and X-ray photoelectron spectroscopy. J. Appl. Electrochem. 1984, 14, 63-74. [CrossRef]

9. Liang, C.L.; Xia, J.L.; Nie, Z.Y.; Luo, X.P. Comparison of Electrochemical Behaviors of Chalcopyrite, Bornite, Chalcocite and Covellite in 9K Medium. Adv. Mater. Res. 2013, 634, 68-71. [CrossRef]

10. Gautier, J.L.; Ortiz, J.; Heller-Ling, N.; Poillerat, G.; Chartier, P. Oxygen reduction on bornite $\left(\mathrm{Cu}_{5} \mathrm{FeS}_{4}\right)$ in alkaline medium. J. Appl. Electrochem. 1998, 28, 827-834. [CrossRef]

11. Pesic, B.; Olson, F.A. Dissolution of bornite in sulfuric acid using oxygen as oxidant. Hydrometallurgy 1984, 12, 195-215. [CrossRef]

12. Bevilaqua, D.; Acciari, H.A.; Benedetti, A.V.; Fugivara, C.S.; Tremiliosi Filho, G.; Garcia, O. Electrochemical noise analysis of bioleaching of bornite $\left(\mathrm{Cu}_{5} \mathrm{FeS}_{4}\right)$ by Acidithiobacillus ferrooxidans. Hydrometallurgy 2006, 83, 50-54. [CrossRef] 
13. Bevilaqua, D.; Acciari, H.A.; Arena, F.A.; Benedetti, A.V.; Fugivara, C.S.; Filho, G.T.; Júnior, O.G. Utilization of electrochemical impedance spectroscopy for monitoring bornite $\left(\mathrm{Cu}_{5} \mathrm{FeS}_{4}\right)$ oxidation by Acidithiobacillus ferrooxidans. Miner. Eng. 2009, 22, 254-262. [CrossRef]

14. Wang, J.; Qin, W.; Zhang, Y.; Yang, C. Bacterial leaching of chalcopyrite and bornite with native bioleaching microorganism. Trans. Nonferr. Metals Soc. China 2008, 18, 1468-1472. [CrossRef]

15. Zhao, H.; Hu, M.; Li, Y.; Zhu, S.; Qin, W.; Qiu, G.; Wang, J. Comparison of electrochemical dissolution of chalcopyrite and bornite in acid culture medium. Trans. Nonferr. Metals Soc. China 2015, 25, 303-313. [CrossRef]

16. Zhao, H.; Wang, J.; Gan, X.; Zheng, X.; Tao, L.; Hu, M.; Li, Y.; Qin, W.; Qiu, G. Effects of pyrite and bornite on bioleaching of two different types of chalcopyrite in the presence of Leptospirillum ferriphilum. Bioresour. Technol. 2015, 194, 28-35. [CrossRef] [PubMed]

17. Hongbo, $Z$. The effect of bacteria on physicochemical properties of porphyrite surface. J. Cent. South Univ. (Nat. Sci. Ed.) 2015, 46, 1-5. [CrossRef]

18. Wang, X.; Liao, R.; Zhao, H.; Hong, M.; Huang, X.; Peng, H.; Wen, W.; Qin, W.; Qiu, G.; Huang, C.; et al. Synergetic effect of pyrite on strengthening bornite bioleaching by Leptospirillum ferriphilum. Hydrometallurgy 2018, 176, 9-16. [CrossRef]

19. Yang, C.-R.; Jiao, F.; Qin, W.-Q. Cu-state evolution during leaching of bornite at 50 degrees C. Trans. Nonferr. Metals Soc. China 2018, 28, 1632-1639. [CrossRef]

20. Zhao, H.B.; Huang, X.T.; Hu, M.H.; Zhang, C.Y.; Zhang, Y.S.; Wang, J.; Qin, W.Q.; Qiu, G.Z. Insights into the Surface Transformation and Electrochemical Dissolution Process of Bornite in Bioleaching. Minerals 2018, 8, 173. [CrossRef]

21. Zhao, H.-B.; Wang, J.; Qin, W.-Q.; Zheng, X.-H.; Tao, L.; Gan, X.-W.; Qiu, G.-Z. Surface species of chalcopyrite during bioleaching by moderately thermophilic bacteria. Trans. Nonferr. Metals Soc. China 2015, 25, 2725-2733. [CrossRef]

22. Silverman, M.P.; Lundgren, D.G. Studies on the chemoautotrophic iron bacterium Ferrobacillus ferrooxidans. II. Manometric studies. J. Bacteriol. 1959, 78, 326-331. [PubMed]

23. Zhao, H.; Wang, J.; Hu, M.; Qin, W.; Zhang, Y.; Qiu, G. Synergistic bioleaching of chalcopyrite and bornite in the presence of Acidithiobacillus ferrooxidans. Bioresour. Technol. 2013, 149, 71-76. [CrossRef] [PubMed]

24. Arce, E.M.; González, I. A comparative study of electrochemical behavior of chalcopyrite, chalcocite and bornite in sulfuric acid solution. Int. J. Miner. Process. 2002, 67, 17-28. [CrossRef]

25. Majuste, D.; Ciminelli, V.S.T.; Osseo-Asare, K.; Dantas, M.S.S.; Magalhães-Paniago, R. Electrochemical dissolution of chalcopyrite: Detection of bornite by synchrotron small angle X-ray diffraction and its correlation with the hindered dissolution process. Hydrometallurgy 2012, 111-112, 114-123. [CrossRef]

26. Bevilaqua, D.; Garcia, O., Jr.; Tuovinen, O.H. Oxidative dissolution of bornite by Acidithiobacillus ferrooxidans. Process Biochem. 2010, 45, 101-106. [CrossRef]

27. Gu, G.-H.; Yang, H.-S.; Hu, K.-T.; Wang, C.-Q.; Xiong, X.-X.; Li, S.-K. Formation of passivation film during pyrrhotite bioleached by pure L. ferriphilum and mixed culture of L. ferriphilum and A. caldus. J. Cent. South Univ. 2015, 22, 880-886. [CrossRef]

28. Gomes, H.I.; Funari, V.; Mayes, W.M.; Rogerson, M.; Prior, T.J. Recovery of Al, Cr and V from steel slag by bioleaching: Batch and column experiments. J. Environ. Manag. 2018, 222, 30-36. [CrossRef] [PubMed]

29. Funari, V.; Makinen, J.; Salminen, J.; Braga, R.; Dinelli, E.; Revitzer, H. Metal removal from Municipal Solid Waste Incineration fly ash: A comparison between chemical leaching and bioleaching. Waste Manag. 2017, 60,397-406. [CrossRef] [PubMed]

30. Khoshkhoo, M.; Dopson, M.; Shchukarev, A.; Sandstrom, A. Electrochemical simulation of redox potential development in bioleaching of a pyritic chalcopyrite concentrate. Hydrometallurgy 2014, 144, 7-14. [CrossRef]

31. Munoz, P.B.; Miller, J.D.; Wadsworth, M.E. Reaction mechanism for the acid ferric sulfate leaching of chalcopyrite. Metall. Mater. Trans. B 1979, 10, 149-158. [CrossRef]

32. Klauber, C.; Parker, A.; van Bronswijk, W.; Watling, H. Sulphur speciation of leached chalcopyrite surfaces as determined by X-ray photoelectron spectroscopy. Int. J. Miner. Process. 2001, 62, 65-94. [CrossRef]

33. Bevilaqua, D.; Diez-Perez, I.; Fugivara, C.S.; Sanz, F.; Benedetti, A.V.; Garcia, O., Jr. Oxidative dissolution of chalcopyrite by Acidithiobacillus ferrooxidans analyzed by electrochemical impedance spectroscopy and atomic force microscopy. Bioelectrochemistry 2004, 64, 79-84. [CrossRef] [PubMed] 
34. Azizi, A.; Petre, C.F.; Olsen, C.; Larachi, F. Untangling galvanic and passivation phenomena induced by sulfide minerals on precious metal leaching using a new packed-bed electrochemical cyanidation reactor. Hydrometallurgy 2011, 107, 101-111. [CrossRef]

35. Tshilombo, A.F. Mechanism and Kinetics of Chalcopyrite Passivation and Depassivation During Ferric and Microbial Leaching. Ph.D. Thesis, University of British Columbia, Vancouver, BC, Canada, 2004.

36. Yang, Y.; Harmer, S.; Chen, M. Synchrotron-based XPS and NEXAFS study of surface chemical species during electrochemical oxidation of chalcopyrite. Hydrometallurgy 2015, 156, 89-98. [CrossRef]

37. Li, Y.; Kawashima, N.; Li, J.; Chandra, A.P.; Gerson, A.R. A review of the structure, and fundamental mechanisms and kinetics of the leaching of chalcopyrite. Adv. Colloid Interface Sci. 2013, 197-198, 1-32. [CrossRef] [PubMed]

38. Krylova, V.; Andrulevicius, M. Optical, XPS and XRD Studies of Semiconducting Copper Sulfide Layers on a Polyamide Film. Int. J. Photoenergy 2009, 2009, 304308. [CrossRef]

39. Ghahremaninezhad, A.; Asselin, E.; Dixon, D.G. Electrodeposition and growth mechanism of copper sulfide nanowires. J. Phys. Chem. C 2011, 115, 9320-9334. [CrossRef]

40. Harmer, S.L.; Thomas, J.E.; Fornasiero, D.; Gerson, A.R. The evolution of surface layers formed during chalcopyrite leaching. Geochim. Cosmochim. Acta 2006, 70, 4392-4402. [CrossRef]

41. Acres, R.G.; Harmer, S.L.; Beattie, D.A. Synchrotron XPS studies of solution exposed chalcopyrite, bornite, and heterogeneous chalcopyrite with bornite. Int. J. Miner. Process. 2010, 94, 43-51. [CrossRef]

42. Acres, R.G.; Harmer, S.L.; Beattie, D.A. Synchrotron XPS, NEXAFS, and ToF-SIMS studies of solution exposed chalcopyrite and heterogeneous chalcopyrite with pyrite. Miner. Eng. 2010, 23, 928-936. [CrossRef]

43. Wang, J.; Gan, X.; Zhao, H.; Hu, M.; Li, K.; Qin, W.; Qiu, G. Dissolution and passivation mechanisms of chalcopyrite during bioleaching: DFT calculation, XPS and electrochemistry analysis. Miner. Eng. 2016, 98, 264-278. [CrossRef]

(C) 2019 by the authors. Licensee MDPI, Basel, Switzerland. This article is an open access article distributed under the terms and conditions of the Creative Commons Attribution (CC BY) license (http:/ / creativecommons.org/licenses/by/4.0/). 